\title{
PELATIHAN DAN PENDAMPINGAN PEMBELAJARAN DARING BERBASIS MOODLE UNTUK GURU FISIKA SMA DI KABUPATEN MALANG SELAMA MASA PANDEMI COVID-19
}

\author{
Purbo Suwasono"1), Sahal Fawaiz'1), Supriyono Koes H. ${ }^{1)}$, Sulur Sulur ${ }^{1)}$, Nugroho Adi P.1) \\ 1)Jurusan Fisika, Fakultas Matematika dan Ilmu Pengetahuan Alam, Universitas Negeri Malang, Malang, Jawa Timur, \\ Indonesia \\ Corresponding author : sahalfawaiz@gmail.com \\ E-mail : purbo.suwasono.fmipa@um.ac.id
}

Diterima 01 Desember 2021, Direvisi 06 Desember 2021, Disetujui 07 Desember 2021

\begin{abstract}
ABSTRAK
Dampak dari pendemi covid-19 memaksa setiap sekolah mewajibkan guru dan siswanya melakukan pembelajaran secara daring dari rumah. Hal tersebut membuat guru dan siswa dalam waktu yang singkat harus mempersiapkan seluruh vasilitas pendukung pembelajaran. Sedangkan di Kabupaten Malang, para guru fisika masih belum begitu akrab dengan pembelajaran daring, maka pendampingan dan pelatihan pembelajaran daring dengan memanfaatkan moodle sangat dibutuhkan. Kegiatan diawali dengan studi literatur dan lapangan, perencanaan, pemberian materi, demosntrasi dan praktek dan diakhiri dengan kegiatan evaluasi. Untuk mengetahui keberhasilan program, kami menyebarkan kueisioner $(n=13$ item) kepada seluruh peserta tentang persepsi terhadap pembelajaran menggunakan moodle dan memantau perkembangan pemahaman guru melalui moodle yang telah dikembangkan. Guru fisika didampingi dan dilatih untuk membuat pembelajaran daring melalui moodle dan variasi model moodle yang sudah pernah diperoleh. Peserta pelatihan dan pendampingan yang diselenggarakan secara daring berjumlah 40 guru fisika di wilayah Kabupaten Malang yang meliputi 34 orang guru fisika SMA dan 6 orang guru fisika MA. Walaupun kehadiran guru tidak bersamaan masuk room meet, tetapi setiap guru selalu masuk setiap hari. Namun, yang aktif mengerjakan pembuatan moodle hanya 25 orang guru yaitu 24 orang guru SMA dan 1 orang guru MA. Peserta yang membuat moodle tersebut bervariasi ada yang hanya membuat Assignment untuk materi dinamika, sampai ada yang lengkap membuat assignment, quiz, dan file untuk materi mekanika, dinamika, usaha dan energi, serta impuls dan momentum. Berdasarkan respon peserta pada angket terkait pelatihan dan pendampingan penyusunan moodle didapatkan $75,19 \%$ peserta merespon baik pembelajaran dengan moodle.
\end{abstract}

Kata kunci: pelatihan-pendampingan; moodle; pandemi covid-19; guru fisika..

\begin{abstract}
The impact of covid-19 outbreaks forced every school to require teachers and students to do online learning from home. This makes teachers and students in a short time must prepare all the learning support facilities. While in Malang Regency, physics teachers are still not so good with online learning, so online learning assistance and training by utilizing moodle is needed. The programme have began with literature and field research, planning, materials provision, demonstrations, and practices, and concludes with evaluation. To assess the program's performance, we provided a questionnaire $(n=13$ questions) to all participants regarding their perceptions of learning with Moodle and simplifying the teacher's knowledge through the produced Moodle. Physics teachers are accompanied and trained to make online learning through moodle and variations of moodle models that have been obtained. The trainees and mentoring held online amounted to 40 physics teachers in malang regency which included 34 high school physics teachers and 6 MA physics teachers. Although the presence of teachers does not coincide with entering the room meet, but every teacher always enters every day. However, who actively do the creation of moodle only 25 teachers, namely 24 high school teachers and 1 MA teacher. Participants who make the moodle vary there are only making Assignments for dynamic materials, until there are complete assignments, quis, and files for mechanical materials, dynamics, work and energy, as well as impulses and momentum. Based on the participants' responses to the questionnaire related to training and mentoring in the preparation of moodle, it was found that $75.19 \%$ of participants responded well to learning with moodle.
\end{abstract}

Keywords: training- mentoring; moodle, pandemic covid-19; physics teacher. 


\section{PENDAHULUAN}

Sejak awal pandemi, pemerintah berusaha memutus rantai penularan covid-19 dengan menerapkan 3M. Program pemerintah tersebut berdampak pada ditutupnya sekolahsekolah untuk pembelajaran luring (Firman \& Rahman, 2020). Pemerintah mewajibkan setiap sekolah untuk melakukan pembelajaran secara daring (Cahyani et al., 2020). Terdapat 23.296 siswa dan 1.381 guru SMA yang dalam pembelajarannya harus dilaksanakan secara daring (Badan Pusat Statistik Kabupaten Malang). Pergantian pembelajaran luring ke pembelajaran daring membutuhkan waktu yang lama, karena tidak bisa serta merta mengganti kurikulum dan proses pembelajarannya (Jusuf et al., 2020). Demikian juga guru dan siswa di wilayah kabupaten malang, sebagian besar belum memahami dan terampil melakukan pembelajaran secara daring (Septian Raibowo \& Yahya Eko Nopiyanto, 2020). Guru perlu dibekali keterampilan pembelajaran daring, agar tetap bisa menjadi fasilitator yang baik bagi siswanya (Subekti \& Kurniawati, 2020).

Jawaban yang terbaik terkait pembelajaran daring adalah pemanfaatan teknologi informasi. Dengan menggunakan teknologi informasi, sesuatu yang jauh bisa menjadi dekat. Interaksi antara guru dengan siswa akan semakin efektif karena bisa mendampingi siswa satu persatu (Conde \& Fonseca, 2018). Dengan teknologi informasi, pembelajaran yang tidak bisa tatap muka, seolah-olah seperti tatap muka. Inilah yang menjadikan moodle sangat banyak digunakan pada proses pembelajaran (Affandi et al., 2020).

Penggunaan teknologi informasi yang belakangan ini sering digunakan berbasis android. Setiap siswa mempunyai HP yang aplikasinya berbasis pada android (Muliyati et al., 2018). Dengan demikian pembelajaran online yang baik jika dapat diakses siswa melalui smartphonenya.

Pemanfaatan e-learning dengan menggunakan moodle, akhir-akhir ini sangat meningkat (Umiyatun et al., 2020). Hal tersebut didukung oleh moodle yang merupakan solusi tepat untuk pembelajaran daring. Pembelajaran dengan memanfaatkan moodle bahkan mampu menyehatkan mental sehingga guru dan siswa dapat menjalani proses belajar mengajar dengan baik (Hasan \& Bao, 2020).

Berdasarkan hasil wawancara dengan ketua MGMP Kabupaten Malang, kebanyakan guru belum menerapkan moodle dalam pembelajarannya. Hal diperkuat dengan hasil ujicoba yang dilakukan pada siswa, dengan memberikan kuis secara online lewat smartphonenya. Sebanyak $89 \%$ siswa masih harus bertanya-tanya pada siswa lainnya bagaimana harus menjalankan aplikasi ini. dengan demikian, guru belum pernah menggunakan fitur kuis selama pembelajarannya di moodle. Hal ini juga diperkuat dengan kunjungan pertama ke SMA Turen secara daring, para guru belum bisa mengunakan fitur-fitur yang ada di moodle.

Temuan lain juga didapatkan selama pertemuan pertama tersebut, guru hanya menggunakan metode ceramah lalu memberi tugas kepada siswanya, tanpa menyertakan aplikasi moodle. Ini menunjukkan pembelajaran berpusat pada siswa belum bisa diterapkan oleh guru secara daring.

Merujuk pada identifikasi masalah yang sudah dijabarkan di atas, maka pelatihan dan pendampingan pemanfaatan moodle untuk mendukung pembelajaran daring di masa pandemi covid-19 ini harus segera dilakukan. Dengan harapan, pembelajaran sain yang dicirikan $5 \mathrm{M}$ dengan jargon student center dapat segera diterapkan pada pembelajaran daring.

\section{METODE \\ Partisipan}

Peserta pelatihan dan pendampingan yang diselenggarakan secara daring berjumlah 40 guru fisika di wilayah Kabupaten Malang yang meliputi 34 orang guru fisika SMA dan 6 orang guru fisika MA. Pada awalnya, pelatihan dan pendampingan hanya dikhususkan guruguru fisika SMA, tetapi terdapat guru MA yang sering ikut pembahasan terkait fisika di MGMP yang bertempat di SMAN 1 Turen Malang, yang tertarik mempelajari moodle dalam pembelajaran fisika.

\section{Studi Literatur dan Studi Lapangan}

Pada tahap ini tim pendampingan dan pelatihan mencari informasi terkait pembelajaran daring yang selama ini terjadi di SMA wilayah MGMP Kabupaten Malang yang berpusat di SMAN 1 Turen Malang. Pada tahap berikutnya, tim pelatihan dan pendampingan mengkaji literatur pembelajaran daring yang efektif dan efisien untuk menunjang pembelajaran daring di MGMP Kabupaten malang tersebut.

\section{Perencanaan}

Berdasarkan studi awal dan studi literatur yang sudah dilakukan, dilakukan perencanaan pelatihan dan pendampingan. Mengingat pelatihan dan pendampingan penggunaan moodle ini daring, maka 1) menyiapkan materi yang nanti akan digunakan untuk materi moodle, 2) menyiapkan materi 
tentang scaffolding untuk menguatkan pembelajaran guru, 3) menyiapkan aplikasi moodle, 4) menyiapkan tutorial memanfaatkan moodle dalam pembelajaran, dan 5) menyiapkan materi terkait pengalaman terbaik yang pernah dilakukan di SMA. Tutorial moodle yang dimaksud adalah tutorial bagaimana menggunakan fitur Assignment, quiz, dan file yang ada di moodle. Pada tahap ini dirancang, guru praktik menggunakan Assignment untuk membuat tugas sekaligus diajarkan mengatur waktu yang ada di fitur Assignment tersebut. Rencananya, pada fitur quiz, guru didampingi dalam membuat quiz di moodle, dengan 3 strategi yaitu soal pilihan ganda, benar salah, dan mencocokkan. Pada fitur file, guru diajarkan bagaimana mengunggah file yang dibutuhkan siswa saat pembelajaran. File bisa berupa materi, LKPD, dan perangkat evaluasi. Selain guru diajari bagaimana menyiapkan pembelajaran dari sudut guru, guru juga diajari bagaimana kalau nanti siswa memanfaatkan moodle dalam pembelajaran. Untuk itu guru juga diajarkan bagaimana mengunggah tugas di fitur assignment dengan memperhatikan waktu yang sudah ditetapkan di moodle, mengerjakan kuis yang sudah ada di moodle, dan mengunduh file yang ada di fitur file. Dengan demikian guru diharapkan tidak hanya tahu bagaimana menggunakan moodle untuk pembelajarannya, tetapi guru bisa mengajarkan kepada siswa bagaimana menggunakan moodle tersebut.

Sebelum itu, mahasiswa yang ikut dalam pendampingan dan pelatihan membuat grup yang anggotanya adalah semua yang terlibat pada pendampingan dan pelatihan moodle ini. Di grup tersebut seluruh kegiatan pelatihan dan pendampingan di kendalikan. Karena pelatihan dan pendampingan moodle dilakukan secara daring, maka seluruh aktivitas seperti penyampaian materi, pendampingan, presensi, pengisian questioner, pengumpulan tugas peserta, pembuatan sertifikat peserta, dan komunikasi peserta, melewati grup tersebut.

\section{Pemberian Materi}

Materi terdiri dari 4 jenis. Materi pertama adalah materi fisika yang nanti akan diajarkan guru. Materi fisika ini meliputi mekanika, dinamika, usaha dan energi, serta impuls dan momentum. Pemberian materi fisika ini dilakukan oleh dosen yang kesehariannya mengampu matakuliah fisika dasar. Materi kedua adalah materi yang terkait dengan scaffolding. Pada materi ini diharapkan peserta paham benar bagaimana menggunakan scaffolding agar pembelajaran yang relative komplek dapat disederhanakan. Scaffolding ini juga diterapkan dengan menggunakan moodle.
Scaffolding yang disajikan meliputi scaffolding procedural dan konseptual. Materi tentang scaffolding ini disampaikan oleh dosen yang kesehariannya mengampu matakuliah pembelajaran fisika dan peneliti pemanfaatan scaffolding untuk pembelajaran. Materi ketiga adalah pemanfaatan moodle untuk pembelajaran. Pada tahap inlah peserta didampingi untuk bisa membuat moodle pembelajaran. Pemateri tentang moodle ini diberikan oleh dosen yang kesehariannya mengampu matakuliah komputasi. Materi yang ke empat adalah praktik baik pembelajaran di SMA pada masa pandemic. Materi ini diampu oleh dosen yang berpengalaman mengajar di SMA dengan menggunakan moodle.

\section{Demonstrasi dan Praktek}

Bagian ini menjelaskan uraian kegiatan pemateri ke tiga yaitu pmanfaatan moodle dalam pembelajaran. Pada awalnya pemateri menunjukkan aplikasi moodle apa saja yang bisa digunakan. Pemateri menunjukkan bahwa menggunakan moodle apa saja, tampilannya akan sama. Pemateri meminta seluruh peserta untuk mulai mengakses e learning dan masuk ke moodle. Pemateri mendemonstrasikan bagaimana memanfaatkan fitur assignment pada moodle. Pemateri meminta setiap peserta mengikuti tahapan yang dilakukan oleh pemateri. Diawali dengan menetapkan judul dan mengisi kotak uraian, peserta harus mengikuti.

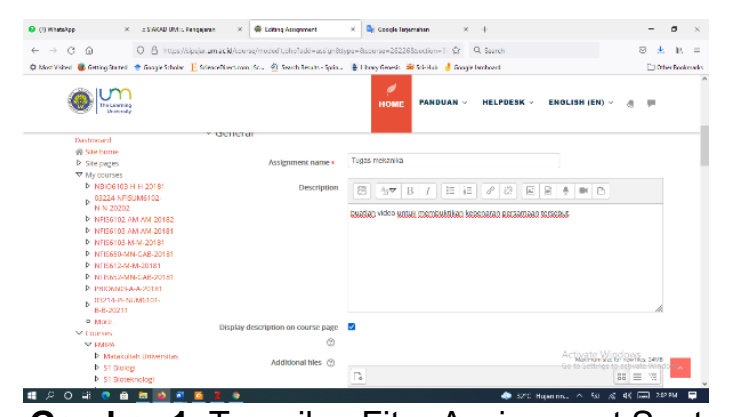

Gambar 1. Tampilan Fitur Assignment Saat Pengisian Judul dan Uraian

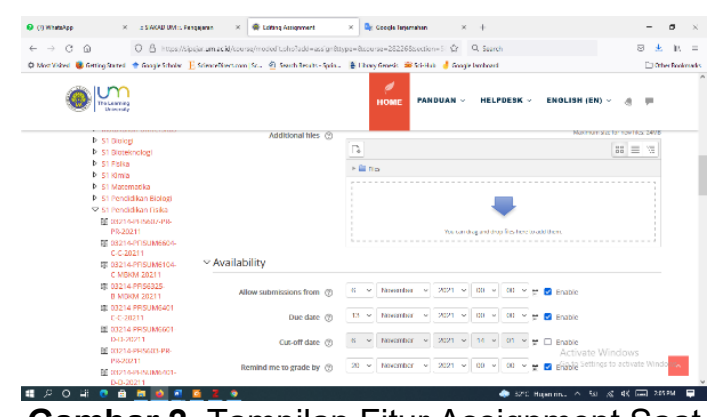

Gambar 2. Tampilan Fitur Assignment Saat Unggah File dan Setting Waktu 
Jika ada peserta yang belum selesai atau belum bisa, maka pemateri mendampingi sampai bisa. Termasuk saat mengunggah file tugas dan menentukan waktu, peserta diminta untuk mengikuti tahap demi tahap.

Demikian juga langkah demi langkah didampingi sampai semua peserta menguasai moodle untuk pembelajarannya.

\section{Evaluasi}

Evaluasi dilakukan bersamaan saat proses pendampingan. Karena pelatihan dan pendampingan ini daring, maka tidak semua peserta dapat diamati kinerjanya oleh tim. Beberapa peserta yang tidak aktif, hanya mendengarkan saja tanpa mengikuti tahapan yang dicontohkan pemateri ketiga. Pada proses pendampingan tersebut juga dapat diketahui ternyata tidak semua peserta yang mengikuti tahapan membuat pembelajaran lengkap melalui moodle. Ada peserta yang mengulangulang terus di fitur asigment dengan alasan agar terampil, tetapi ada juga yang lengkap mengikuti tahapan pemateri sehingga mampu menggunakan moodle tidak hanya assignment, tetapi juga fitur quiz dan file. Bahkan ada yang bisa sampai empat materi fisika yang ditargetkan, yaitu mekanika, dinamika, usaha dan energi, serta impuls dan momentum.

Evaluasi juga dilakukan dengan memberikan kuesioner kepada peserta. Kuesioner digunakan untuk menggali pendapat peserta terkait kemanfaatan pelatihan dan pendampingan, serta untuk mengetahui tindak lanjut peserta setelah pelatihan dan pendampingan selesai.

Dari kelima kriteria minimal penilaian sesuai dengan standar penilaian pengabdian kepada masyarakat (Kemdikbud, 2020). Kami memfokuskan tiga kriteria penilaian yaitu, a) tingkat kepuasan guru; b) terjadinya perubahan sikap, pengetahuan dan keterampilan para guru terhadap penggunaan moodle selama pembelajaran jarak jauh; c) dapat dimanfaatkannya teknologi pembelajaran menggunakan moodle secara berkelanjutan. Terdapat 13 item yang mewakili ketia kriteria penilaian.

Tabel 1. Item Kuesioner berdasarkan Kriterianya

\begin{tabular}{|c|c|c|}
\hline No & Item & Kriteria \\
\hline 1. & $\begin{array}{l}\text { Saya menilai pembelajaran } \\
\text { dengan moodle cocok untuk } \\
\text { siswa saat ini }\end{array}$ & $\mathrm{b}$ \\
\hline 2. & $\begin{array}{l}\text { Saya menilai pembelajaran } \\
\text { dengan moodle bermanfaat } \\
\text { untuk meningkatkan kualitas } \\
\text { belajar siswa }\end{array}$ & b \\
\hline 3. & 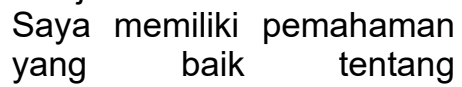 & b \\
\hline
\end{tabular}

pembelajaran dengan moodle

Saya menilai pembelajaran dengan moodle merupakan

4. model pembelajaran yang mengikuti perkembangan zaman

Saya menduga semangat

5. belajar siswa terbina dengan pembelajaran dengan moodle

6. Saya dapat memanfaatkan IT untuk pembelajaran.

Saya merasa sulit b

7. menyiapkan pembelajaran dengan moodle itu.

8. Saya menilai pembelajaran dengan moodle bisa memfasilitasi siswa untuk belajar mandiri

9. Saya yakin pembelajaran dengan moodle membantu siswa menilai diri sendiri.

10. Saya merasa materi workshop membantu saya merencanakan pembelajaran dengan moodle.

11. Saya dapat melaksanakan pembelajaran dengan moodle.

12. Saya akan terus berusaha untuk dapat menerapkan pembelajaran dengan moodle

13. Saya merasa waktu yang a dipergunakan dalam pemberian materi cukup

Sebagai tolak ukur keberhasilan program pendampingan dan pelatihan pembelajaran daring berbasis moodle, kami mengacu terhadap kategori yang digunakan oleh Asrial et al., (2020). Seperti pada Tabel 2 berikut.

Tabel 2. Kategori dari Kuesioner Persepsi

Guru terhadap Pembelajarn Menggunakan

\begin{tabular}{cc}
\multicolumn{2}{c}{ Moodle } \\
\hline Interval Skor & Kategori \\
\hline $20-36$ & Sangat buruk \\
$36,1-52$ & Buruk \\
$52,1-68$ & Cukup \\
$68,1-84$ & Baik \\
$84,1-100$ & Sangat Baik \\
\hline
\end{tabular}

\section{HASIL DAN PEMBAHASAN}

Merujuk dari hasil observasi awal di Kabupaten Malang cabang MGMP Turen, belum ditemukan moodle yang sudah diintegrasikan di website sekolah. Sebagian 
kecil sudah menggunakan platform yang disediakan kementrian tetapi tidak dikoordinir dengan baik, sehingga terkesan masih individual. Perbedaan platform tersebut mengakibatkan siswa merasa bingung untuk mengikuti pembelajaran dari yang ditetapkan guru-gurunya. Siswa harus mengikuti lima platform pembelajaran daring yaitu Microsoft Teams, Google Clasroom, Edmodo, Moodle, dan WhatsApp.

Ke depan MGMP Kabupaten Malang dengan Kelola SMAN 1 Turen memilih hosting dan domain dengan memilih paket satu tahun dengan alamat link https://mgmpkabmalang.net/. Walaupun pandemi segera berakhir, tetapi masih bisa digunakan untuk membantu pembelajaran luring jika dibutuhkan

Saat proses pendaftaran melalui googleform, peserta juga diminta mengisi username dan email yang digunakan sebagai akun e-learning. Peserta didesain memiliki course masing-masing untuk melakukan praktek secara langsung dalam mendesain pembelajaran online.

Pelaksanaan kegiatan dilaksanakan selama 4 hari dengan rincian sebagai berikut. Hari ke 1, Pkl. 08.00-16.00, Tanggal 22 Agustus 2020: Tugas Mandiri Guru Mengidentifikasi RPP, hari ke 2, 29 Agustus 2020: Workshop Peningkatan Kompetensi Guru dalam mengembangkan moodle pembelajaran fisika, Hari ke 3, 5 September 2020: Workshop Peningkatan Kompetensi Guru dalam menggunakan moodle pembelajaran fisika, dan hari ke 4, Pkl. 08.00-16.00, Tanggal 12 September 2020: Tugas Mandiri Guru menyusun moodle pembelajaran fisika, selain yang sudah menjadi materi workshop.

Peserta yang aktif mengerjakan pembuatan moodle hanya 25 orang guru yaitu 24 orang guru SMA dan 1 orang guru MA. Peserta yang membuat moodle tersebut bervariasi ada yang hanya membuat Assignment untuk materi dinamika, sampai ada yang lengkap membuat Assignment, quiz, dan file untuk materi mekanika, dinamika, usaha dan energi, serta impuls dan momentum.

Peserta yang menjawab setuju dan sangat setuju untuk pertanyaan "Saya menilai pembelajaran dengan moodle cocok untuk siswa saat ini" sebanyak $32(80,00 \%)$. Peserta merasa bahwa platform pembelajaran daring yang efektif dan efisien adalah moodle (ĐukićMirzajanc, 2019).

Peserta yang menjawab setuju dan sangat setuju untuk pertanyaan "Saya menilai pembelajaran dengan moodle bermanfaat untuk meningkatkan kualitas belajar siswa" sebanyak 32 (80,00\%). Pembelajaran yang menarik untuk siswa generasi 4.0 adalah pembelajaran yang melibatkan IT (Manan et al., 2020). Moodle adalah platform yang bisa diakses oleh siswa melalui smartphonenya, sehingga sangat berpotensi untuk meningkatkan kualitas belajar siswa.

Peserta yang menjawab setuju dan sangat setuju untuk pertanyaan "Saya memiliki pemahaman yang baik tentang pembelajaran dengan moodle" sebanyak 25 (62,50\%). Pelatihan dan pendampingan yang hanya dilakukan efektif hanya dua hari dirasa sangat kurang jika targetnya peserta benar-benar faham dan trampil menggunakan moodle. Untuk terampil dan menggunakan moodle membutuhkan rasa senang dan fasilitas yang memadahi (De Medio et al., 2020).

Peserta yang menjawab setuju dan sangat setuju untuk pertanyaan "Saya menilai pembelajaran dengan moodle merupakan model pembelajaran yang mengikuti perkembangan zaman" sebanyak 35 (87,50\%). Pembelajaran dengan platform moodle mempunyai ciri-ciri pembelajaran generasi 4.0. Pembelajaran dengan moodle dapat diakses di mana saja dan terkait dengan materi yang lain. Pembelajaran dengan moodle adalah pembelajaran interakstif yang berarti siswa bisa belajar dengan berinteraksi dengan moodle selayaknya berinteraksi dengan guru (Distante et al., 2020).

Peserta yang menjawab setuju dan sangat setuju untuk pertanyaan "Saya menduga semangat belajar siswa terbina dengan pembelajaran dengan moodle" sebanyak $30(75,00 \%)$. Generasi 4.0 adalah generasi yang sangat akrap dengan IT terutama yang bisa diakses melalui smatrphonenya. Moodle sangat menjawab akan kesenangan siswa tersebut (Wijiastuti et al., 2019). Dengan demikian siswa akan semangat jika pembelajaran dengan moodle.

Peserta yang menjawab setuju dan sangat setuju untuk pertanyaan "Saya dapat memanfaatkan IT untuk pembelajaran." sebanyak $25 \quad(62,50 \%)$. Jumlah tersebut menunjukkan adanya kemampuan dasar ang tidak begitu akrab dengan IT dan kewajiban untuk memvasilitasi siswa generasi 4.0. Masih ada peserta $(37,75 \%)$ yang belum memanfaatkan IT untuk pembelajaran. Keengganan peserta tersebut disebabkan kurang akrapnya peserta dengan IT mengingat perkembangan teknologi begitu pesat (Surahman, 2019).

Peserta yang menjawab setuju dan sangat setuju untuk pertanyaan "Saya merasa sulit menyiapkan pembelajaran dengan moodle itu." sebanyak 15 (37,50\%). Tuntutan pembelajaran modern menyebabkan guru 
harus terus belajar menyesuaikan termasuk dalam pembelajaran. Dengan adanya pendampingan dan pelatihan penyusunan pembelajaran menggunakan moodle, membuat guru semakin akrap dengan moodle (Ngibad et al., 2020).

Peserta yang menjawab setuju dan sangat setuju untuk pertanyaan "Saya menilai pembelajaran dengan moodle bisa memfasilitasi siswa untuk belajar mandiri" sebanyak 34 (85,00\%). Peserta menyadari bahwa moodle bisa didesain interaktif. Fitur di quis misalnya, bisa diatur sehingga bisa digunakan ajang penjajakan pengetahuan bagi siswa. Fitur quiz itu dapat diajak berinteraksi oleh siswa layaknya guru (Kerimbayev et al., 2020). Fitur quiz dapat didesain memberikan balikan terhadap semua jawaban yang dipilih oleh siswa.

Peserta yang menjawab setuju dan sangat setuju untuk pertanyaan "Saya yakin pembelajaran dengan moodle membantu siswa menilai diri sendiri." sebanyak 34 (85,00\%). Peserta mendapat pengetahuan bahwa moodle dapat digunakan siswa untuk menilai diri sendiri. Kembali ke fitur quiz. Pada fitur quis, dapat diatur bisa menilai setiap pekerjaan siswa. Bisa diatur setiap kali menjawab satu butir soal langsung ada balikan skor yang diperoleh atau, setelah selesai mengerjakan soal baru mendapatkan skor secara total, walaupun tetap bisa melihat skor tiap butir instrumen. Siswa dengan mudah bisa mengukur kemampuannya sendiri sekaligus bisa mempelajari kekurangannya berdasarkan balikan dari moodle (Schweighofer et al., 2019).

Peserta yang menjawab setuju dan sangat setuju untuk pertanyaan "Saya merasa materi workshop membantu saya merencanakan pembelajaran dengan moodle." sebanyak 36 (90,00\%). Pendampingan dengan tahap demi tahap, menyebabkan peserta mampu menggunakan moodle pada pembelajaran daring. Tidak hanya itu, peserta juga menyadari bahwa tanpa moodle, pembelajaran daring akan susah untuk dilaksanakan sesuai dengan tuntutan kurikulum. Dengan moodle, peserta akhirnya menyadari bahwa moodle sangat membantu peserta dalam merencanakan pembelajaran daring (Anggraeni \& Sole, 2018).

Peserta yang menjawab setuju dan sangat setuju untuk pertanyaan "Saya dapat melaksanakan pembelajaran dengan moodle." sebanyak 25 (62,50\%). Moodle merupakan sarana yang baik untuk pembelajaran daring. Dengan demikian jika peserta mampu memahami dan trampil memanfaatkan moodle, maka sangat mempermudah pembelajaran (Papadakis et al., 2018). Siswa merasa senang karena moodle sesuai dengan eranya siswa, dan pembelajaran tidak terbatas pada lingkup local tetapi juga internasional.

Peserta yang menjawab setuju dan sangat setuju untuk pertanyaan "Saya akan terus berusaha untuk dapat menerapkan pembelajaran dengan moodle." sebanyak 35 $(87,50 \%)$. Ketertarikan peserta terhadap moodle sangatlah rasional. Moodle berisi 17 activities dan 7 resources. Peserta yang baru mendapat 2 activities (assignment dan quiz) dan 1 resource (file), merasakan betapa besar manfaat moodle untuk pembelajaran daring, maka rasional jika ingin meningkatkan pembelajarannya dengan terus menggunakan moodle. Moodle merupakan sarana pembelajaran yang sangat efektif dan efisien untuk membagun pembelajaran daring (Zabolotniaia et al., 2020).

Peserta yang menjawab setuju dan sangat setuju untuk pertanyaan "Saya merasa waktu yang dipergunakan dalam pemberian materi cukup." sebanyak 23 (57,50\%). Untuk bisa terampil menggunakan moodle dalam pembelajaran daring, waktu 2 hari efektif sangatlah singkat. Sedangkan tuntutan pembelajaran daring begitu banyak. Sebenarnya fitur-fitur di moodle sudah sangat memadahi untuk memenuhi tuntutan pembejaran daring (Fayanto et al., 2019).

Dari 13 pertanyaan yang sudah dijawab peserta, maka diperoleh grafik pada Gambar 3.
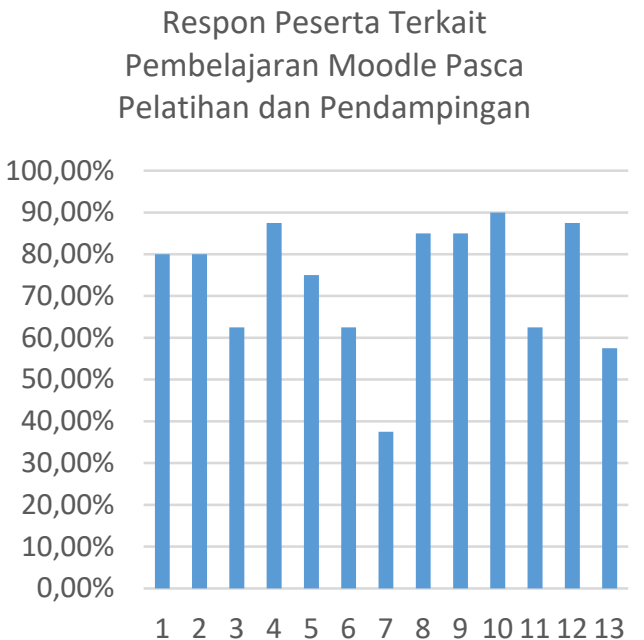

Gambar 3. Grafik Persentasi Respon Peserta Terkait Pelatihan dan Pendampingan Pembelajaran Moodle

Dengan memasukkan angka positif pertanyaan ke 7 , sehingga menjadi $62,50 \%$ (100 - 37,50), maka rerata respon peserta pada angket terkait pelatihan dan pendampingan penyusunan moodle didapatkan $75,19 \%$ peserta merespon baik pembelajaran dengan moodle. 


\section{SIMPULAN DAN SARAN}

Pelatihan dan pendampingan guru fisika di wilayah MGMP Kabupaten Malang mencapai efektivitas $75,19 \%$ dengan kategori baik. Pendampingan dengan menuntun langkah demi langkah dalam pemanfaatan moodle untuk pembelajaran fisika, merupakan strategi yang baik bagi peserta. Namun, masih diperlukan dukungan dari lingkungan sekitar peserta untuk menindaklanjuti kegiatan pelatihan dan pendampingan pemanfaatan moodle untuk pembelajaran fisika.

\section{UCAPAN TERIMAKASIH}

Kami mengucapkan terima kasih banyak kepada pihak MGMP Fisika Kabupaten Malang dan seluruh pihak yang membantu lancarnya kegiatan pelatihan dan pendampingan. Pengabdian Masyarakat ini didanai penuh oleh PNBP FMIPA Universitas Negeri Malang.

\section{DAFTAR RUJUKAN}

Affandi, M. R., Widyawati, M., \& Bhakti, Y. B. (2020). ANALISIS EFEKTIVITAS MEDIA PEMBELAJARAN ELEARNING DALAM MENINGKATKAN HASIL BELAJAR SISWA SMA PADA PELAJARAN FISIKA. Jurnal Pendidikan Fisika, 8(2), 150. https://doi.org/10.24127/jpf.v8i2.2910

Anggraeni, D. M., \& Sole, F. B. (2018). ELearning Moodle, Media Pembelajaran Fisika Abad 21. Jurnal Penelitian Dan Pengkajian IImu Pendidikan: E-Saintika, 1(2), 57. https://doi.org/10.36312/esaintika.v1i2.101

Asrial, A., Syahrial, S., Maison, M., Kurniawan, D. A., \& Piyana, S. O. (2020). Ethnoconstructivism E-Module to Improve Perception, Interest, And Motivation of Students in Class V Elementary School. JPI (Jurnal Pendidikan Indonesia), 9(1), 30-41. https://doi.org/10.23887/jpiundiksha.v9i1.19222

Cahyani, A., Listiana, I. D., \& Larasati, S. P. D. (2020). Motivasi Belajar Siswa SMA pada Pembelajaran Daring di Masa Pandemi Covid-19. IQ (IImu Al-Qur'an): Jurnal Pendidikan Islam, 3(01), 123140. https://doi.org/10.37542/iq.v3i01.57

Conde, M. Á., \& Fonseca, D. (2018). Information society skills: Is knowledge accessible for all? Part I. Universal Access in the Information Society, 17(2), 223-227. https://doi.org/10.1007/s10209-0170547-7

De Medio, C., Limongelli, C., Sciarrone, F., \& Temperini, M. (2020). MoodleREC: A recommendation system for creating courses using the moodle e-learning platform. Computers in Human Behavior, 104, 106168. https://doi.org/10.1016/j.chb.2019.106 168

Distante, D., Villa, M., Sansone, N., \& Faralli, S. (2020). MILA: A SCORM-Compliant Interactive Learning Analytics Tool for Moodle. 2020 IEEE 20th International Conference on Advanced Learning Technologies (ICALT), 169-171. https://doi.org/10.1109/ICALT49669.20 20.00056

Đukić-Mirzajanc, M. (2019). The effectiveness of learning German on Moodle. Inovacije u Nastavi, 32(3), 130-150. https://doi.org/10.5937/inovacije19031 30D

Fayanto, S.-, Kawuri, M. Y. R. T., Jufriansyah, A., Setiamukti, D. D., \& Sulisworo, D. (2019). Implementation E-Learning Based Moodle on Physics Learning in Senior High School. Indonesian Journal of Science and Education, 3(2), 93. https://doi.org/10.31002/ijose.v3i2.117 8

Firman \& Rahman. (2020). Pembelajaran Online di Tengah Pandemi Covid-19. 2020, 02, 9.

Hasan, N., \& Bao, Y. (2020). Impact of "eLearning crack-up" perception on psychological distress among college students during COVID-19 pandemic: A mediating role of "fear of academic year loss." Children and Youth Services Review, 118, 105355. https://doi.org/10.1016/j.childyouth.202 0.105355

Jusuf, H., Sobari, A., \& Fathoni, M. (2020). Pengaruh Pembelajaran Jarak Jauh Bagi Siswa SMA Di Era Covid-19: -. Jurnal Kajian IImiah, 1(1), 15-24. https://doi.org/10.31599/jki.v1i1.212

Kemdikbud. (2020). PERATURAN MENTERI PENDIDIKAN DAN KEBUDAYAAN REPUBLIK INDONESIA NOMOR 3 TAHUN 2020 TENTANG STANDAR NASIONAL PENDIDIKAN TINGGI.

Kerimbayev, N., Nurym, N., Akramova, A., \& Abdykarimova, S. (2020). Virtual educational environment: Interactive communication using LMS Moodle. Education and Information Technologies, 25(3), 1965-1982. 
https://doi.org/10.1007/s10639-01910067-5

Manan, N. A., Emzir, \& Rahmat, A. (2020). Moodle-Based Speaking Learning Model. Journal of Physics: Conference Series, $\quad 1477, \quad 042009$. https://doi.org/10.1088/17426596/1477/4/042009

Muliyati, D., Bakri, F., \& Ambarwulan, D. (2018). APLIKASI ANDROID MODUL DIGITAL FISIKA BERBASIS DISCOVERY LEARNING. WaPFi (Wahana Pendidikan Fisika), 3(1), 74. https://doi.org/10.17509/wapfi.v3i1.109 44

Ngibad, K., Herawati, D., Ekawati, E. R., \& Pradana, M. S. (2020). Pelatihan Elearning berbasis Moodle untuk DosenDosen Fakultas IImu Kesehatan Universitas Maarif Hasyim Latif Sidoarjo. Darmabakti : Jurnal Pengabdian Dan Pemberdayaan Masyarakat, 1(1). https://doi.org/10.31102/darmabakti.20 20.1.1.13.-18

Papadakis, S., Kalogiannakis, M., Sifaki, E., \& Vidakis, N. (2018). Evaluating Moodle use via Smart Mobile Phones. A case study in a Greek University. EAI Endorsed Transactions on Creative Technologies, 5(16), 156382. https://doi.org/10.4108/eai.10-42018.156382

Schweighofer, J., Taraghi, B., \& Ebner, M. (2019). Development of a Quiz Implementation of a (Self-) Assessment Tool and its Integration in Moodle. International Journal of Emerging Technologies in Learning (IJET), 14(23), 141. https://doi.org/10.3991/ijet.v14i23.1148 4

Septian Raibowo \& Yahya Eko Nopiyanto. (2020). PROSES BELAJAR MENGAJAR PJOK DI MASA PANDEMI COVID-19. STAND : Journal Sports Teaching and Development, 1(2), 112-119. https://doi.org/10.36456/jstand.v1i2.2774

Subekti, A. S., \& Kurniawati, L. A. (2020). Pelatihan Mendesain Pembelajaran Daring Menarik Selama Pandemi Covid-19 dengan Teknologi Pembelajaran Sederhana. Dinamisia: Jurnal Pengabdian Kepada Masyarakat, 4(4), 588-595. https://doi.org/10.31849/dinamisia.v4i4 .4679
Surahman, E. (2019). INTEGRATED MOBILE LEARNING SYSTEM (IMOLES) SEBAGAI UPAYA MEWUJUDKAN MASYARAKAT PEBELAJAR UNGGUL ERA DIGITAL. JINOTEP (Jurnal Inovasi Dan Teknologi Pembelajaran) Kajian Dan Riset Dalam Teknologi Pembelajaran, 5(2), 50-56. https://doi.org/10.17977/um031v5i220 $19 \mathrm{p} 050$

Umiyatun, U., Purnomo, M. E., \& Indrawati, S. (2020). Moodle Based Worksheet on Scientific Article Writing: A Students Perceptions. Jurnal Pendidikan Progresif, 10(1), 117-132. https://doi.org/10.23960/jpp.v10.i1.202 013

Wijiastuti, A., Roesminingsih, M. V., Ardianingsih, F., Masithoh, S., Riyanto, E., \& Andajani, S. J. (2019). Design Science Education for Student with Special Needs Use Learning Management System Platform Moodle. 2019 5th International Conference on Education and Technology (ICET), 9497.

https://doi.org/10.1109/ICET48172.201 9.8987207

Zabolotniaia, M., Cheng, Z., Dorozhkin, E., \& Lyzhin, A. (2020). Use of the LMS Moodle for an Effective Implementation of an Innovative Policy in Higher Educational Institutions. International Journal of Emerging Technologies in Learning (IJET), 15(13), 172. https://doi.org/10.3991/ijet.v15i13.1494 5 
Volume 5, Nomor 1, Desember 2021.

p-ISSN : 2614-5251

e-ISSN : 2614-526X 